\title{
ANALISA EKSPERIMENTAL GAYA POTONG, TERMAL DAN GETARAN PADA AKTUATOR TELESKOP GALAH PMANEN KELAPA SAWIT
}

\author{
Padan E Simanjorang ${ }^{1 *}$, Muhammad Sabri², Arif Fadillah Nasution ${ }^{3}$ \\ Departemen Teknik Mesin, Fakultas Teknik, Universitas Sumatera Utara \\ Jalan Dr. T. Mansyur No. 9, Padang Bulan, Kec. Medan Baru, Kota Medan, Sumatera Utara 20222, Indonesia \\ *Email: simanjorangpadan@gmail.com
}

\begin{abstract}
ABSTRAK
Salah satu faktor yang paling banyak mempengaruhi pertumbuhan dan produktivitas kelapa sawit adalah faktor panen. Besarnya frekuensi panen dibutuhkan suatu inovasi alat pemanen untuk memenuhi kebutuhan panen agar dapat meningkatkan efektivitas dalam proses panen kelapa sawit. Oleh karena itu penulis akan menganalisa Linear Aktuator teleskop galah pemanen kelapa sawit yang telah dirancang oleh tim harvesting palm tool. Jenis aktuator ini dirancang dengan menggunakan baterai sebagai sumber tegangan listrik yang disalurkan pada koil dan berubah menjadi energi mekanik yang menggerakkan poros secara linear yang berguna untuk menggerakkan pisau potong. Adapun tujuan dari penelitian ini adalah untuk mengetahui kecepatan potong dari Linear Aktuator, mengukur fluktuasi temperatur pada poros dan casing serta mengetahui pola getaran tanpa beban dari aktuator. Dari hasil penelitian yang dilakukan, energi yang dihasilkan aktuator adalah $7126 \mathrm{Nm}$ dimana aktuator ini masih belum mampu melakukan proses pemotongan. Saat dilakukan pengukuran temperatur, fluktuasi tertinggi temperatur pada poros ada pada lokasi uji 2 dengan suhu $65,67^{\circ} \mathrm{C}$ dan fluktuasi tertinggi pada casing $64,55^{\circ} \mathrm{C}$ dimana lokasi uji 2 ini merupakan lokasi yang bersentuhan langsung dengan koil.
\end{abstract}

Kata kunci: Linear Aktuator, Gaya Potong, Temperatur.

\begin{abstract}
One of the factors that most influence the growth and productivity of oil palm is the harvest factor. The large frequency of harvesting requires an innovative harvesting tool to meet the needs of the harvest in order to increase the effectiveness of the oil palm harvesting process. Therefore, the authors will analyze the Linear Actuator telescope for palm oil harvester that has been designed by the palm tool harvesting team. This type of actuator is designed using a battery as a source of electric voltage which is supplied to the coil and turned into mechanical energy that moves the shaft linearly which is useful for moving the cutting knife. The purpose of this study is to determine the cutting speed of the Linear Actuator, measure temperature fluctuations on the shaft and casing and determine the no-load vibration pattern of the actuator. From the results of the research conducted, the energy produced by the actuator is $7126 \mathrm{Nm}$ where this actuator is still unable to perform the cutting process. When the temperature measurement was taken, the highest fluctuation of temperature on the shaft was at test location 2 with a temperature of $65.67^{\circ} \mathrm{C}$ and the highest fluctuation was on casing $64.55{ }^{\circ} \mathrm{C}$ where test location 2 was a location in direct contact with the coil.
\end{abstract}

Keywords: Linear Actuator, Cutting Force, Temperature

\section{PENDAHULUAN}

Salah satu faktor yang paling banyak mempengaruhi pertumbuhan dan produktivitas kelapa sawit ini adalah faktor panen. Untuk memenuhi kebutuhan panen ini dibutuhkan sebuah peralatan sebagai sarana penunjang pekerjaan dalam hal pemanenan buah kelapa sawit, maka perlu adanya suatu alat bantu pemanenan untuk mempermudah pekerjaan yang dilakukan dan tentunya dengan mempertimbangkan 
masalah kesehatan dan keselamatan kerja serta ramah terhadap lingkungan. Sebelumnya memang sudah ada inovasi-inovasi mengenai peralatan pemanenan buah kelapa sawit ini tetapi masih banyak terdapat kelemahan-kelemahan, salah satunya seperti yang peneliti telah sebutkan diatas. Oleh sebab itu peneliti akan merancang sebuah Linear Aktuator pada alat pemanenan buah kelapa sawit.

Pada pembuatan alat pemanen kelapa sawit ini, penulis merancang alat ini dengan memanfaatkan sistem linear actuator merupakan rancangan sebuah alat yang sederhana dan sangat bermanfaat bagi perusahaan maupun perorangan pada sektor perkebunan kelapa sawit dengan perancangan desain yang ringan. Perancangan produk alat pemanen TBS ini masih dalam skala kecil dengan kemampuan kerja yang ringan dengan konsep yang sangat sederhana

\section{TEORI DASAR}

\subsection{Linear Actuator}

Pada instrumentasi aktuator sebagai output terakhir untuk melanjutkan perintah dari controller yang akan melakukan tindakan eksekusi. Berdasarkan daya yang dihasilkan actuator dapat diklasifikasikan sebagai berikut:

1. Aktuator Elektrik

Aktuator elektrik merupakan aktuator yang mempunyai prinsip kerja mengubah sinyal elektrik menjadi gerakan mekanik.

2. Aktuator Hidrolik

Aktuator hidrolik merupakan actuator yang memanfaatkan aliran fluida / oli bertekanan menjadi gerakan mekanik.

3. Aktuator Pneumatik

Aktuator yang memanfaatkan udara bertekanan menjadi gerakan mekanik. Dengan memberikan udara bertekanan pada satu sisi permukaan piston (arah maju) sedangkan sisi yang lain (arah mundur) terbuka ke atmosfer, maka gaya diberikan pada sisi permukaan piston tersebut sehingga batang piston akan terdorong keluar sampai mencapai posisi maksimum dan berhenti.

\subsection{Solenoida}

Solenoida adalah perangkat elektromagnetik yang dapat mengubah energi listrik menjadi energi gerakan. Energi gerakan yang dihasilkan oleh solenoida biasanya hanya gerakan mendorong dan menarik. Pada dasarnya, Solenoid hanya terdiri dari sebuah kumparan listrik yang dililitkan di sekitar tabung silinder dengan aktuator ferro-magnetic atau sebuah plunger yang bebas bergerak masuk dan keluar dari bodi kumparan.

Solenoida terdiri atas solenoida linier dan solenoida rotasi sebagai berikut:

1. Solenoida Linier

Solenoid Linier adalah alat elektromagnetik atau elektromekanis yang mengubah energi listrik menjadi sinyal magnetik atau energi gerakan mekanis.

Solenoid jenis ini disebut dengan solenoid linier karena plunger atau aktuatornya bergerak secara linier. Solenoid linier tersedia dalam dua bentuk konfigurasi dasar yaitu solenoid linier tipe tarik yang dapat menarik beban kearah dirinya apabila diberi arus listrik dan solenoida linear tipe dorong yang dapat mendorong beban menjauhi dirinya apabila diberikan arus listrik secukupnya. Solenoida linier dapat dilihat seperta Gambar 2.1

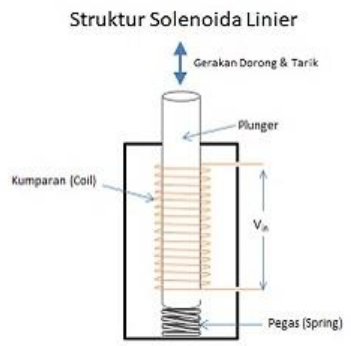

Gambar 2.1 Solenoida Linier ${ }^{[17]}$

2. Solenoida Rotasi

Solenoid jenis rotasi ini dapat digunakan untuk mengantikan fungsi motor DC kecil ataupun motor stepper yang sudut gerakannya sangat kecil. Berdasarkan sudut gerakannya solenoid rotasi tersedia dalam sudut gerakan $25^{\circ}, 35^{\circ}, 45^{\circ}, 60^{\circ}$ dan $90^{\circ}$. Jenis solenoida rotasi terlihat seperti gambar 2.2 


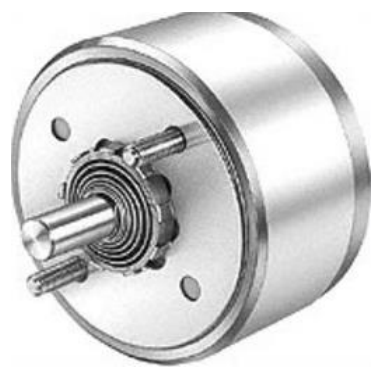

Gambar 2.2 Solenoida Rotasi ${ }^{[17]}$

Solenoid Rotasi dapat menghasilkan gerakan rotasi ketika diberikan energi atau arus listrik ataupun pada saat berubah polaritas medan elektromagnetik. Solenoid Rotasi terdiri dari gulungan listrik yang dililitkan di sekitar rangka baja dengan disk magnetik yang terhubung ke poros output yang berada di atas koil.

Pada saat diberikan arus listrik, medan elektromagnetik menghasilkan kutub-kutub utara dan kutub-kutub selatan yang menolak kutub magnet permanen yang berdekatan sehingga menyebabkannya berputar pada sudut yang ditentukan oleh konstruksi mekanis solenoid rotasi.

\subsection{Motor DC}

Motor DC adalah motor listrik yang memerlukan suplai tegangan arus searah pada kumparan medan untuk diubah menjadi energi gerak.

Motor DC memerlukan suplai tegangan yang searah pada kumparan medan untuk diubah menjadi energi mekanik.

Keuntungan utama motor DC adalah kecepatannya mudah dikendalikan dan tidak mempengaruhi kualitas pasokan daya. Motor DC ini dapat dikendalikan dengan mengatur tegangan dinamo dan arus medan. Dengan meningkatkan tegangan dinamo akan meningkatkan kecepatan. Sebaliknya dengan menurunkan arus medan dapat meningkatkan kecepatan. Gambar 2.3 menunjukkan prinsip kerja motor DC.

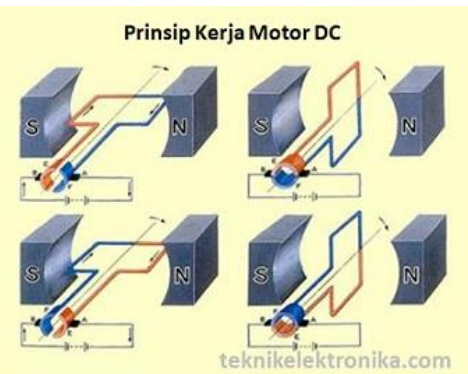

\section{Gambar 2.3 Prinsip Kerja Motor DC ${ }^{[2]}$}

Daya listrik adalah jumlah energi yang diserap atau dihasilkan dalam sebuah rangkaian. Sumber energi seperti tegangan listrik akan menghasilkan daya listrik sedangkan beban yang terhubung dengannya akan menyerap daya listrik tersebut. Dengan kata lain daya listrik adalah tingkat konsumsi energi dalam sebuah sirkuit atau rangkaian listrik. Rumus yang digunakan untuk menghitung daya listrik adalah sebagai berikut:

$$
P=\text { V.I....... }
$$

Dimana hubungan daya listrik dengan energi yang dihasilkan adalah

$$
\mathrm{W}=\text { F.v.t }
$$

\subsection{Getaran}

Umumnya getaran dapat didefinisikan sebagai gerakan bolak-balik suatu benda dari posisi awal melalui titik kesetimbangannya. Ilustrasi paling sederhana menjelaskan getaran adalah mekanisme pegas yang diberi massa pada ujungnya.

Setiap komponen mekanikal memiliki berat dan properties yang menyerupai pegas. Ada dua kelompok getaran yang umum yaitu getaran bebas dan getaran paksa. Getaran bebas terjadi jika sistem berosilasi karena bekerjanya gaya yang ada dalam sistem itu sendiri atau tidak ada gaya luar yang bekerja. Sistem yang bergetar bebas akan bergetar pada satu atau lebih frekuensi naturalnya. Getaran yang terjadi karena rangsangan gaya luar disebut getaran paksa. Jika rangsangan tersebut berosilasi maka sistem dipaksa untuk bergetar pada frekuensi eksitasinya. Jika frekuensi eksitasi sama dengan frekuensi natural maka sistem terjadi resonansi yang sangat membahayakan.

Getaran terdiri atas getaran bebas dan getaran paks. 
1. Getaran Bebas

Getaran bebas adalah kemampuan suatu benda untuk melakukan getaran tanpa diberikan gaya luar yang merupakan fungsi waktu. Dalam gerak translasi perpindahan didefinisikan sebagai jarak linear, dalam gerak rotasi perpindahan didefinisikan sebagai gerakan sudut.

2. Getaran Paksa

Getaran paksa adalah getaran yang terjadi karena adanya rangsangan dari gaya luar. Getaran pada pengujian ini adalah getaran bebas atau getaran natural karena getaran yang terjadi berasal dari gerak translasi dari solenoida pada linear actuator.

\section{HASIL DAN PEMBAHASAN}

\subsection{Set-Up Linear Actuator}

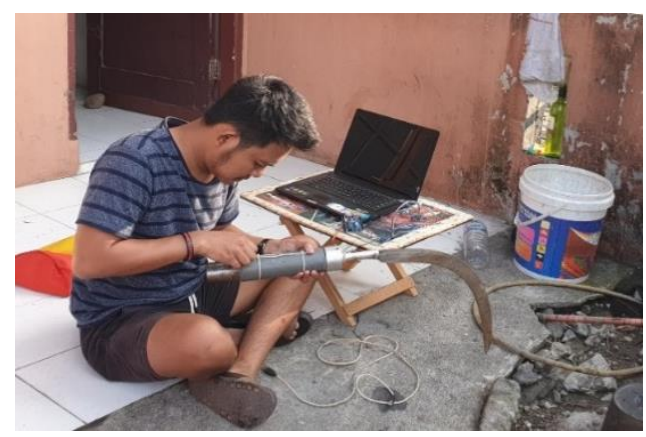

Gambar 3.1 Set-Up Linear Actuator

\subsection{Pengujian Gaya Potong}

Adapun hasil pengujian gaya potong ditampilkan dengan membandingan data pengujian gaya potong pelepah dari team pisau palm harvesting tools dengan gaya $(\mathrm{F})$ yang dihasilkan aktuator kemudian data tersebut dikonversikan menjadi energi $(\mathrm{Nm})$. Hasil pengukuran gaya dan perbandingan energi yang dihasilkan ditunjukkan pada Tabel 3.1

Tabel 3.1 Gaya dan Energi yang dihasilkan Aktuator

\begin{tabular}{|c|c|c|c|c|}
\hline No & Daya (Watt) & Banyak Tarikan & Gaya $(\mathrm{N})$ & Energi $(\mathrm{Nm})$ \\
\hline 1 & 120 & 1 & 923,07 & 35,99 \\
\hline 2 & 120 & 2 & 1846,14 & 71,98 \\
\hline 3 & 120 & 3 & 2769,21 & 107,97 \\
\hline 4 & 120 & 4 & 3693,28 & 143,96 \\
\hline
\end{tabular}

Tabel 3.2 Gaya dan Energi yang dibutuhkan untuk memotong Pelepah Kelapa Sawit

\begin{tabular}{|c|c|c|}
\hline No & Gaya Potong $(\mathrm{N})$ & Energi $(\mathrm{Nm})$ \\
\hline 1 & 819,81 & 25,22 \\
\hline 2 & 822,62 & 40,36 \\
\hline 3 & 2457,75 & 141,33 \\
\hline 4 & 3270,79 & 906,33 \\
\hline
\end{tabular}

Kemudian dibandingkan gaya yang dihasilkan Linear Actuator dengan gaya yang dibutuhkan untuk memotong pelepah kelapa sawit yang ditunjukkan pada tabel 3.3

Tabel 3.3 Data perbandingan gaya Linear Actuator dengan Gaya Potong Pelepah

\begin{tabular}{|c|c|c|c|c|}
\hline No & $\mathrm{F}_{\text {pelepah }}(\mathrm{N})$ & $\mathrm{F}_{\text {aktuator }}(\mathrm{N})$ & $\mathrm{W}_{\text {pelepah }}(\mathrm{Nm})$ & $\mathrm{W}_{\text {aktuator }}(\mathrm{Nm})$ \\
\hline 1 & 819,81 & 923,07 & 25,22 & 35,99 \\
\hline 2 & 822,62 & 923,07 & 25,22 & 35,99 \\
\hline
\end{tabular}


Jurnal Dinamis USU, Vol. 9, No. 1 (Bulan, Tahun) |06-21

\begin{tabular}{|l|l|l|l|l|}
\hline 3 & 2457,75 & 2769,21 & 141,33 & 107,97 \\
\hline 4 & 3270,79 & 3693,28 & 906,33 & 143,96 \\
\hline
\end{tabular}

Dari tabel 3.3 dapat diketahui gaya yang dihasilkan aktuator untuk sekali tarikan adalah 923,07 $\mathrm{N}$ lebih besar dari gaya yang dibutuhkan untuk memotong pelepah kelapa sawit yaitu sebesar 819,81 $\mathrm{N}$ dalam sekali tarikan.

\subsection{Pengukuran Temperatur}

Pengukuran temperatur dilakukan untuk mengetahui perpindahan panas yang terjadi akibat adanya arus listrik pada poros dan casing pada Linear Actuator. Pengukuran temperatur pada poros dilakukan pada tiga lokasi. Dimana lokasi pengukuran dapat dilihat pada gambar 3.2

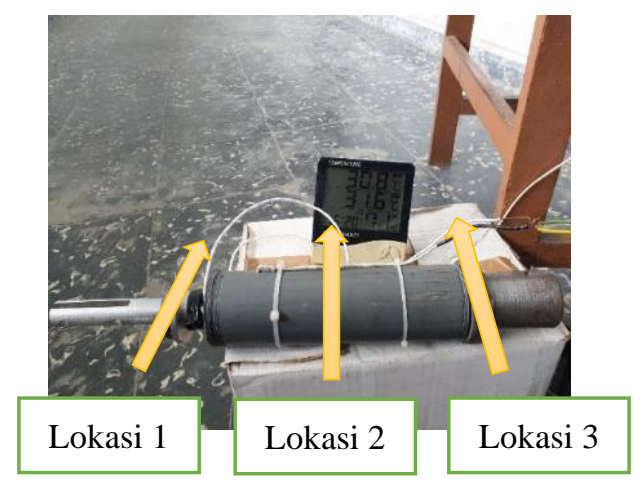

Gambar 3.2 Pengukuran Temperature

\subsubsection{Pengukuran pada poros}

Pengukuran temperatur pada poros dilakukan pada tiga lokasi. Hasil pengukuran pada poros ditunjukkan pada tabel 3.4 .

Tabel 3.4 Temperatur vs Waktu pada poros

\begin{tabular}{|c|c|c|c|}
\hline \multirow{2}{*}{ Time (s) } & \multicolumn{3}{|c|}{ Temperatur pada Poros $\left({ }^{\circ} \mathrm{C}\right)$} \\
\cline { 2 - 4 } & Lokasi 1 & Lokasi 2 & Lokasi 3 \\
\hline 30 & 30,68 & 30,68 & 28 \\
\hline 60 & 35,55 & 35,85 & 28 \\
\hline 90 & 39,45 & 39,55 & 28 \\
\hline 120 & 43,55 & 43,55 & 28 \\
\hline 150 & 47,55 & 48,55 & 28 \\
\hline 180 & 50,85 & 51,55 & 28 \\
\hline 210 & 55,51 & 55,75 & 28 \\
\hline 240 & 59,56 & 60,55 & 28 \\
\hline 270 & 62,55 & 62,44 & 28 \\
\hline 300 & 65,57 & 65,67 & 28 \\
\hline
\end{tabular}

Pengukuran dilakukan selama 300 detik dan data yang dimasukkan setiap 30 detik. Dari data pengukuran dapat ditampilkan pada grafik seperti pada gambar 3.3 


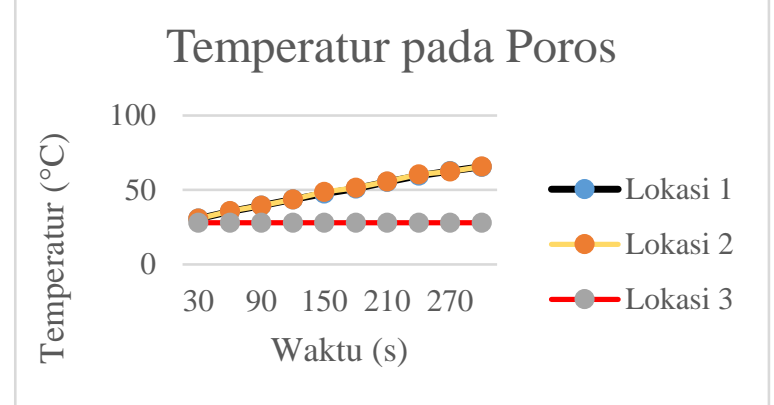

Gambar 3.3 Temperatur vs Waktu pada poros

\subsubsection{Pengukuran pada casing}

Pengukuran temperatur pada poros dilakukan pada tiga lokasi. Hasil pengukuran pada poros ditunjukkan pada tabel 3.5 .

Tabel 3.5 Temperatur pada casing

\begin{tabular}{|c|c|c|c|}
\hline \multirow{2}{*}{$\begin{array}{c}\text { Waktu } \\
(\mathrm{s})\end{array}$} & \multicolumn{3}{|c|}{ Temperatur pada Casing $\left({ }^{\circ} \mathrm{C}\right)$} \\
\cline { 2 - 4 } & $\begin{array}{c}\text { Location } \\
1\end{array}$ & $\begin{array}{c}\text { Location } \\
2\end{array}$ & $\begin{array}{c}\text { Location } \\
3\end{array}$ \\
\hline 30 & 29,29 & 31,45 & 28,00 \\
\hline 60 & 31,45 & 35,24 & 28,00 \\
\hline 90 & 33,57 & 41,87 & 28,05 \\
\hline 120 & 36,33 & 43,55 & 28,05 \\
\hline 150 & 38,55 & 47,35 & 28,15 \\
\hline 180 & 41,54 & 50,85 & 28,19 \\
\hline 210 & 43,31 & 54,25 & 28,30 \\
\hline 240 & 46,73 & 57,56 & 28,40 \\
\hline 270 & 48,56 & 61,33 & 28,62 \\
\hline 300 & 50,47 & 64,55 & 28,84 \\
\hline
\end{tabular}

Tabel 3.5 menunjukkan perubahan temperatur yang diukur selama 300. Hasil pengukuran ini dapat dimasukkan pada grafik seperti pada gambar 3.4

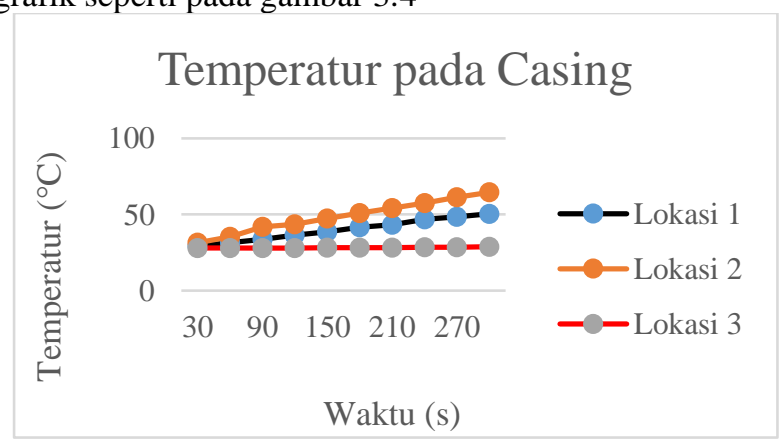

Gambar 3.4 Temperatur vs Waktu pada Casing

\subsection{Pengujian Pola Getaran}

Pengujian pola getaran dilakukan dengan menggunakan media kertas milimeter. Pada ujung linear aktuator dikaitkan pena secara vertikal. Kemudian saaat actuator dihidupkan pensil diarahkan ke kertas milimeter dan kemudian kertas ditarik secara perlahan untuk mengetahui pola getaran seperti pada Gambar 3.5 


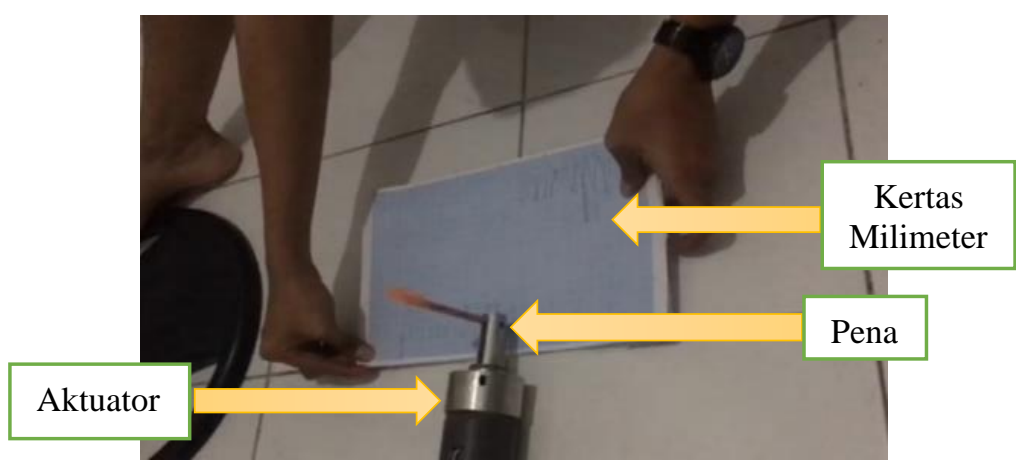

Gambar 3.5 Pengukuran Pola Getaran

Pengujian dilakukan sepanjang kertas milimeter ataupun selama 20 detik. Berikut grafik hasil pengujian pola getaran pertama.

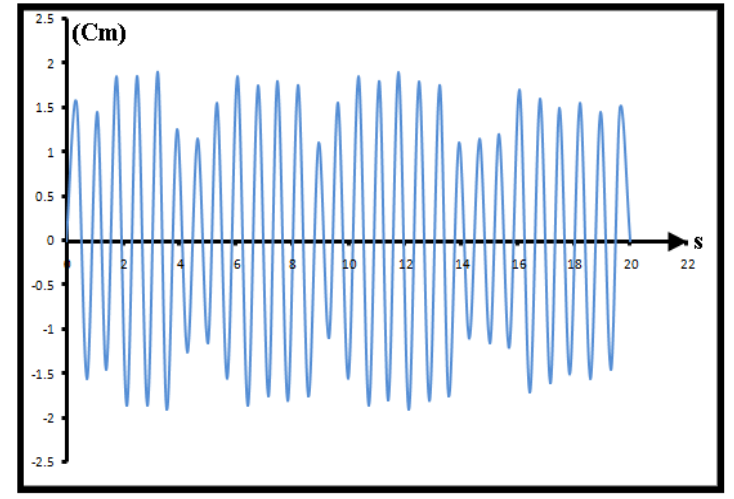

Gambar 3.6 Grafik Pengujian Pola Getaran Pertama

Berikut ini merupakan hasil pengukuran pola getaran kedua.

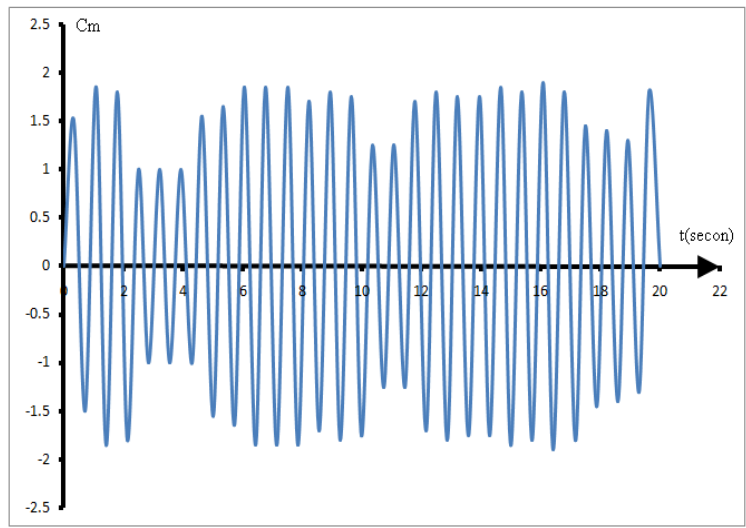

Gambar 3.7 Grafik Pengujian Pola Getaran Kedua

Dari data grafik pengukuran maka dilakukan pengukuran dan perhitungan periode dan frekuensi getaran serta banyak getaran yang terjadi yang ditunjukkan pada table 3.5

Tabel 3.5 Hasil Pengukuran Pola Getaran

\begin{tabular}{|c|c|}
\hline $\begin{array}{c}\mathbf{n} \text { (banyak } \\
\text { getaran }\end{array}$ & 27,5 \\
\hline $\mathbf{t}$ (sekon) & 20 \\
\hline $\begin{array}{c}\mathbf{f} \text { (frekuensi) } \\
\mathbf{n} / \mathbf{t}\end{array}$ & $1.374 \mathrm{hz}$ \\
\hline $\begin{array}{c}\text { kec sudut } \\
\mathbf{2 \pi f}\end{array}$ & $\begin{array}{c}8.6428 \\
\mathrm{rad} / \mathrm{sekon}\end{array}$ \\
\hline $\mathbf{T}$ (periode) & 0.727 \\
\hline
\end{tabular}




\section{$1 / \mathbf{f}$}

\section{KESIMPULAN DAN SARAN}

\subsection{Kesimpulan}

Berdasarkan penelitian serta analisa yang telah dilakukan maka penulis dapat menyimpulkan beberapa hal berikut:

1. Gaya potong terbesar yang dihasilkan dari Linear Actuator adalah sebesar 3693,28 N dimana ini sedikit lebih besar dari gaya potong pelepah yaitu $3270,29 \mathrm{~N}$.

2. Fluktuasi temperature tertinggi pada casing berada pada titik 2 yaitu pada tengah casing yang bersentuhan dengan rumah koil, setelah dihitung selama 300 s suhunya sebesar $64,55^{\circ} \mathrm{C}$. Sedangkan pada titik 3 temperaturnya konstan.

Fluktuasi temperatur tertinggi pada poros juga terjadi pada titik 2, dimana titik ini yang bersentuhan langsung dengan rumah koil yaitu sebesar $65,67^{\circ} \mathrm{C}$. Sedangkan pada titik 3 temperturnya konstan.

3. Pola getaran yang diuji pada media kertas millimeter selama 20 detik sebanyak 27.5 getaran dengan frekuensi $1.375 \mathrm{~Hz}$.

\subsection{Saran}

Dalam suatu penelitian pasti mengalami kendala dalam pengerjaan nya. Dalam penelitian ini peneliti pun mengalami hal yang sama. Peneliti juga memiliki beberapa saran kepada peneliti selanjutnya demi terciptanya alat pemanen kelapa sawit yang lebih efisien dimasa depan. Adapun sarannya yaitu:

1. Peneliti selanjutnya menggunakan material yang paramagnetik untuk mendapatkan medan magnet yang kuat.

2. Peneliti selanjutnya perlu menggunakan sumber daya yang lebih besar untuk mendapatkan torsi yang lebih besar

3. Perlu diperhatikan bagaimana agar koil tidak mengalami panas yang berlebihan.

\section{REFERENSI}

[1] Akhmad, Hafez Fahrizal, 2019, Materi Aktuator, Makalah, Institut Sepuluh November.

[2] Hery, S, 2018, Analisa Daya dan Kontrol Kecepatan Motor Pada Alat Bantu Las Rotary Positioner, skripsi, Jurusan Teknik Mesin, Universitas Ibn Khaldun Bogor.

[3] Sularso, Kiyokatsu S. Dasar Perencanaan dan Pemilihan Elemen Mesin.11978 Jakarta: Pradnya Paramita

[4] Ibrahim , AW , Widodo, TW , Supardi , TW . 2016. Sistem control torsi pada motor DC 6(1): 93 $-104$

[5] Antonov, Oktariani, Y. Pengaruh torsi beban terhadap kinerja motor induksi tiga fase. 5(1): 9 15

[6] Buyung, S. Analisis perbandingan daya dan torsi pada alat pemotong rumput elektrik (APRE. 3 (1): $1-4$

[7] Susilo, A, Yunianto, M, Variani, VI. Simulasi gerak harmonik sederhana dan osilasi teredam pada cassy-E 524000 2(2): $124-137$

[8] Susastriawan, A. (2011). Perpindahanpanas \& massa: Konduksi. https://agungsthermal.files.wordpress.com/2011/04/heat-transfer.pdf, diakases 10 agustus 2016.

[9] Syaifurahman. (2014). Pengaruh dimensi kumparan terhadap efisiensi energy pada sistem pengiriman daya listrik tanpa kabel. 6(2): 10 - 13

[10] Effendi, Herry. 2015. Karakteristik Getaran Sistem 2 DOF Dengan Penambahan Single Dynamic Vibration Absorber (DVA), Skripsi, Jurusan Teknik Mesin, Institut Teknologi Sepuluh November.

[11] Widyamurti, Tunggul. 2014. Perancangan Aktuator ${ }_{\mathrm{p} H}$ Dan Kelembaban Pada Sistem Live Cell Chamber", Skripsi, Jurusan Teknik Elektro, Universitas Brawijaya.

[12] Permatasari, Prisca. 2010. Studi Pengaruh Diameter Kawat dan Susunan Kumparan Terhadap Voltase Bangkitan pada mekanisme Pemanen Energi Getaran, Skripsi, Jurusan Teknik Mesin, Fakultas Teknik Industri, Institut Teknologi Sepuluh Nopember.

[13] Khalifah, Ayu Nur. 2015. Analisis Pengaruh Jumlah dan Panjang Kumparan Luar Terhadap Daya Keluaran Pada Hubbard Coil. Skripsi, Jurusan Fisika, Fakultas Sains Dan Teknologi, Universitas Islam Negeri Maulana Malik Ibrahim Malang

[14] Ibrahim, A. W., 2014, Upgrading Driver Motor DC di Pinch Roll CTCM PT. KS, Krakatau Steel, Cilegon 
[15] Gunarta, Lilik. 2011. Beberapa Jenis Induktor Harga Rendah. Ensiklopedia

[16] Nasution, Arif, 2020, Inovasi Alat Pemanen Tandan Buah Segar (TBS) Dengan Sistem Mekanikal Elektronik Ramah Lingkungan

[17] Mardiansyah, Riki, 2012, Potensi Medan Elektromagnetik Sebagai Sumber Pembangkit Tenaga Listrik. Skripsi, Teknik Elektro, Fakultas Teknik, Universitas Indonesia.

[18] Pujiastuti, Lulu, 2014, Perancangan dan Implementasi Sistem Kendali Solenoid Pada Proses Pemisahan Otomatis Minyak dan Air Menggunakan Programmable Logic Control (PLC). Skripsi, Jurusan Fisika, Fakultas Sains dan Matematika, Universitas Dipenogoro 